Article

\title{
The Diversity Distribution Pattern of Ruderal Community under the Rapid Urbanization in Hangzhou, East China
}

\author{
Mingli Zhang ${ }^{1,2}$, Kun Song ${ }^{1,3,4, *}$ and Liangjun Da ${ }^{1,3,4, *}$ \\ 1 School of Ecological and Environmental Sciences, East China Normal University, Shanghai 200241, China; \\ ymqz78@126.com \\ 2 Hangzhou Vocational \& Technical College, Hangzhou 310018, China \\ 3 Shanghai Key Laboratory for Ecology of the Urbanization Process and Eco-restoration, East China Normal \\ University, Shanghai 200241, China \\ 4 Institute of Eco-Chongming, Shanghai 200241, China \\ * Correspondence: ksong@des.ecnu.edu.cn (K.S.); ljda@des.ecnu.edu.cn (L.D.)
}

Received: 4 March 2020; Accepted: 19 March 2020; Published: 23 March 2020

\begin{abstract}
The process of rapid urbanization has affected the composition and diversity of urban vegetation species. The process of urbanization from 2000 was analyzed in the area of "one major city with three vice cities and six groups", according to the urban master planning of Hangzhou from 2001 to 2020. The results show that dramatic changes have occurred for land use types during the ten years from 2000 to 2010 in Hangzhou, of which urban land has become the main type of land use and the area of arable land has presented serious loss. This study found that the Gramineae and Compositae species were the main groups of ruderals in 1665 quadrats, which reflected the characteristics of a few large families. The number of Monotypic and Oligotypic family/genera accounted for $67.3 \%$ of the total number of families and $97.5 \%$ of the total number of genera. The ruderals were dominated by annual life forms with strong adaptability and high plasticity. The ruderal communities in the study areas were divided into 125 community types based on clustering analysis of the dominance of ruderal species. The proportion of summer annual ruderals in the dominant species of ruderal communities gradually decreased along the group-vice city-major city gradient. The percentage of winter annual ruderals was the highest and the percentage of perennials was the lowest in the groups. The number of ruderal community types showed a nonlinear decreasing trend along the urbanization gradient of the group-vice city-major city. The number of ruderal communities in the vice cities and the groups was similar, which was higher than that in the major city. Only species that are highly tolerant to urban habitats can be distributed under frequent and high-intensity human disturbances in the major city. Therefore, the number of ruderal communities in the major city was minimal and it had low diversity.
\end{abstract}

Keywords: land use type; ruderal community; species diversity; urbanization gradient

\section{Introduction}

The process of rapid urbanization has caused continuous changes in land use patterns; specifically, the coverage of hard paving in urban construction is expanding. The exchange of water and gas between soil and air is blocked since natural soil is enclosed under the hardened surface [1]. Natural water bodies and wetlands are shrinking and urban soils are becoming drier under the rapid urbanization process due to the continuous expansion of urban lands, including buildings, roads, and drainage measures. These changes have led to the aridification of urban habitats [2,3], which affects the normal growth of urban plants and also forms a heterogeneous urban landscape of fragmental habitats in variety 
of urban lands [4-6]. The heterogeneous urban landscape, in turn, results in diverse micro-habitats clustering in a relatively small area, which allows for plenty of species to coexist [7]. There is a large number of human disturbance activities in urban habitats; for instance, the spatial location, species composition, succession stage, and site conditions of urban vegetation are all affected by different levels of human disturbance activities $[8,9]$. These alterations in land use patterns have led to changes in the environmental conditions that plants in urban areas depend on, which results in alterations in the species diversity, the community structure, and the spatial pattern of urban vegetation [10-13].

As an important part of urban vegetation, ruderal species have been studied since the 1970s. Studies exist regarding ruderal community types [14], the diversity and distribution of invasive ruderals [15,16], and the dynamic changes of ruderals [17-19] along urbanization gradients. These studies show that the distribution of urban ruderal communities is related to soil structure and soil nutrients $[20,21]$. Ruderal species diversity and community types show a trend of gradually increasing from urban centers to surrounding areas [22-24].

To date, ruderal vegetation research in China has mainly focused on farmland ruderals, lawn ruderals, and exotic invasive ruderals. Regarding the main research on ruderals in urban greening the focus has been on ruderal species, life forms, dominant species, and control and greening applications [25-29], but few study focus on how ruderal community structure varies along urbanization gradients.

The size of the city of Hangzhou has rapidly expanded as a result of urbanization over the past 30 years. This rapid urbanization process has greatly affected the living environment and the diversity of urban ruderals in Hangzhou [30,31]. The present study is an attempt to analyze the distribution pattern of ruderal species diversity and demonstrate the influence of urbanization on ruderal species component. We aim to answer the following questions: (i) How has land use and land cover changed between 2000 and 2010; (ii) what are the characteristics of ruderal flora and species diversity; and, (iii) what is the distribution pattern of ruderal communities in urbanization gradient? The present study provides scientific support for the local government in terms of ruderal management, and it constructs a solid basis for further in-depth research on the distribution pattern of ruderal species.

\section{Methods}

\subsection{Study Area}

Hangzhou, which is the capital city of Zhejiang Province, is located in the lower reaches of the Qiantang River on the southeast coast of China. Hangzhou has a subtropical monsoon climate with an average annual temperature of $16.2^{\circ} \mathrm{C}$ and an average annual precipitation of $1100 \sim 1600 \mathrm{~mm}$. The terrain of Hangzhou is diverse, which is low in the east and high in the west. The plain is in the northeast and the low hills are in the south, west, and center. There are many kinds of soils, and the soil properties are quite different due to geomorphological factors and the variable soil-forming environment. Laterite soil distributes the most widely, accounting for more than half of the total soil area (Hangzhou City Records 2003). The zonal vegetation is comprised of subtropical evergreen broad-leaved forest, which is mainly composed of species, such as Fagaceae, Lauraceae, Theaceae, and Magnoliaceae (Hangzhou Ecological City Construction Plan 2006).

Hangzhou has 10 urban districts, one country-level city, and two counties. The city covers a total area of $16,850 \mathrm{~km}^{2}$, of which the urban area takes up $8289 \mathrm{~km}^{2}$. The population number reached 10.36 million and the urbanization level reached 78.5\% by 2019 in Hangzhou. Hangzhou's GDP was 1.53 trillion and the per capita income was 59,261 yuan in 2019. With the continuous increase in the degree of urbanization, the urban area has dramatically expanded, forming the urban planning of "one major city, three vice cities, and six groups", with West Lake as the core (Urban master planning (2001-2020) (Country Letter (2007) No. 19)). The "one major city" is the main urban area and it is the political, economic, scientific, and information center. Vice cities are sub-cities that respond to the main city in space, complement its functions, and have relative independence; each vice city is a new node 
that is formed by the urban population and the production factors in the process of outward diffusion. Here, the "three vice cities" refer to Jiangnan City, Xiasha City, and Linping City, and the "six groups" can be divided in two parts-the north and the south. The north part includes Tangxi, Liangzhu, and Yuhang, while the south part includes Linpu, Guali, and Yipeng.

\subsection{Sampling Methods}

Ruderal communities were collected by field surveys from April to November in 2015 and 2016. Wulin Square was selected as the urban center of Hangzhou. The study area was divided into three zones along the urbanization gradient by interpreting and analyzing the satellite images of land cover in Hangzhou in 2000 and 2010. The first zone was the major city (M). The second zone was the vice cities (V), including Jiangnan City (VJ), Xiasha City (VX), and Linping City (VL). The third zone was the groups (G), including Tangxi Group (GT), Liangzhu Group (GZ), Yuhang Group (GY), Linpu Group (GL), Guali Group (GG), and Yipeng Group (GP) (Figure 1).

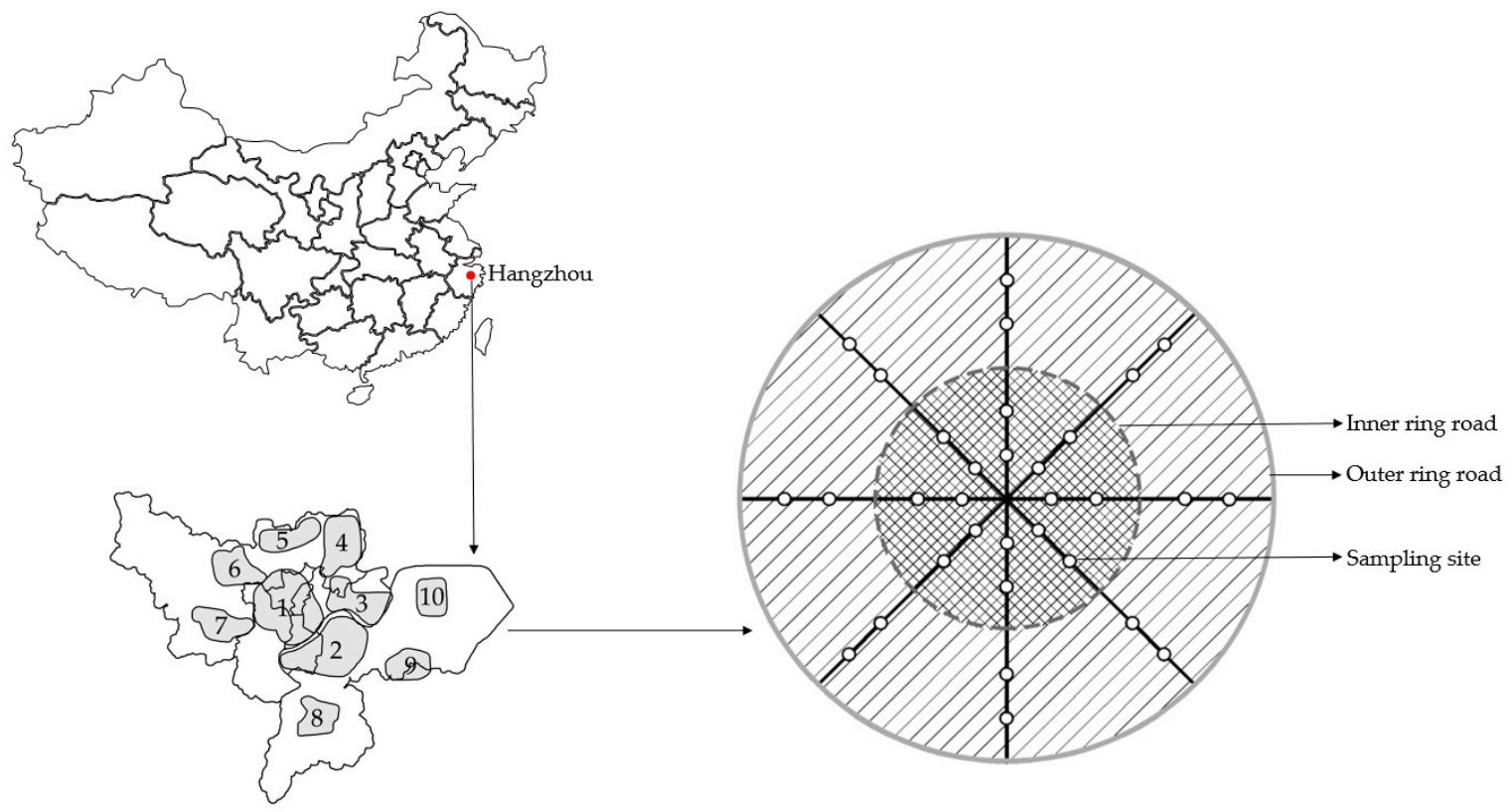

Figure 1. Location of the study area in Hangzhou city, China. Ten grey regions (bottom left panel) are included in the field survey for two seasons. No. 1 is the main city; No. $2-4$ (vice cities) are Jiangnan City, Xiasha City, and Linping City, respectively; No. 5-10 (groups) are Tangxi Group, Liangzhu Group, Yuhang Group, Linpu Group, Guali Group, and Yipeng Group, respectively. For each region (bottom right panel), the inner circle zone is the urbanized area in 2000, while the outer ring zone is the urbanized area in 2010. Sixteen sampling sites were selected in the inner circle and the outer ring, respectively, where the distance between two sampling sites was $0.6 \mathrm{~km}$. We randomly surveyed five quadrats at each sampling site.

Each of the above-mentioned ten regions could be divided into two parts, namely, inner circle zone and outer ring zone. Urban areas in 2000 were considered to be the inner circle zone, while areas that were transformed into urban areas were considered as the outer ring zone during 2000 and 2010. We selected 16 sampling sites in the inner circle and the outer ring, respectively, where the distance between two sampling sites was $0.6 \mathrm{~km}$. We randomly surveyed five quadrats at each sampling sites, and the size of each quadrat was generally $1 \mathrm{~m} \times 1 \mathrm{~m}$. We surveyed the quadrats in both spring (from April to June) and autumn (from September to November), to catch almost all ruderal species, including summer annual ruderal (growth season between March and December) and winter annual ruderal (growth season between October and May of the next year). Thus, for two season surveys, we planned to survey 3600 sampling quadrats. However, some of them (such as hard paving, 
water bodies, buildings, etc.) without vegetation were excluded from the surveys. Finally, the data of 1665 quadrats were collected. In each quadrat, the species were identified and the maximum height and coverage were estimated for each species. In each quadrat, only the maximum height of a species was measured by a tapemeasure. In our survey, we estimate coverage based on canopy cover, which is a vertical projection of the outermost perimeter of the natural spread of foliage of plants. We did estimate at the height of c. $1.5 \mathrm{~m}$, depending on the height of investigator, because the ruderal usually lower than $1 \mathrm{~m}$. Combined with the collected species coverage data, the dominance of each species was calculated, which was used to determine the dominant species in each quadrat.

\subsection{Data Processing and Analysis}

\subsubsection{Species' Origin}

The ruderal species were identified according to China Academy of Science's [32] and Zhejiang Academy of Science and Technology's [33] guidelines. The plants recorded in this study were divided into four categories according to the numbers of species in each family: Monotypic (family with one species), Oligotypic (family with $2-4$ species), Mesotypic (family with 5-14 species), and Plurimotypic (family with more than 14 species)". The terms of "Monotypic, Oligotypic, Mesotypic, and Plurimotypic" are often used in the analysis of flora composition [34].

\subsubsection{Areal Type}

The present study determined the distributions of ruderal species according to the origin information of species [32] and the classification criteria of Chinese seed plant families and genera [35]. The distributions were divided into four categories: cosmopolitan, tropical, temperate, and endemic in China.

\subsubsection{Life Form and Growth}

The present study classified ruderal life form into either annual or perennial according to the criteria for the classification of life history characteristics [36-38]. Annual ruderals were further divided into two kinds of dormancies, including summer annual and winter annual, while perennial ruderals were further divided into three dormant types, including geophyte, hemicryptophyte, and chamaephyte. The growth forms were categorized into eight groups [39] for the classification of species growth form, and they were further classified into either small form (Branched, Climbing or liane, Procumbent, Rosette, Tussock) or large form (Erect, Partial rosette, Pseudo-rosette), according to their height $[40,41]$.

\subsubsection{Community Characteristics}

This study used the relative dominance values of the species to characterize their abundance within the community. The dominance of a species is calculated as product of maximum height and coverage of the species to determine the dominant species. Subsequently, the number of dominant species within each quadrat was identified using the dominance analysis method [42]. We wrote a self-defined function for dominant species determination in R 3.2.0 (R Core Team 2015) (Figure A1). The data from the quadrats were subjected to a cluster analysis (group linkage method: Group average; distance measure: Euclidean distance) while using PC-ORD 5.0 (MjM Software Design, Gleneden Beach, OR, USA) for the relative dominance data for each species [43,44]. The ruderal communities were divided based on the results of the cluster analysis, and were named according to their dominant species (Appendix A.2). 


\subsubsection{Species Diversity}

Two indices were used to measure the diversity in each quadrat: species richness $(\mathrm{S})$ and the Shannon-Wiener index of diversity (H) [45],

$$
\mathrm{H}=-\sum_{i=1}^{S} P_{i} \ln P_{i}
$$

where $P_{i}$ is the relative dominance of a species as a proportion between 0 and 1 , and $S$ is the total number of species.

To calculate the diversity index, the diversity function in the Vegan package (version 2.5-6) (Community Ecology Package, Jari Oksanen, Finland, 2013) was used. All of the calculations were run in R 3.2.0 (R Core Team 2015).

The significant differences of the species diversity indices were tested in different regions while using a one-way ANOVA with post-hoc Tukey HSD test, which was carried out through SPSS 23.0 Software.

\subsection{Analysis of the Impact of Urbanization}

To classify land use in 2000 and 2010, we used a SPOT high-resolution image of Hangzhou in 2000 and a Landsat ETM+ (Enhanced Thematic Mapper) multi-spectral remote sensing image from 2010 with a resolution of $30 \mathrm{~m}$. Meanwhile, the administrative vector map of Hangzhou Municipality, the map of land use in Hangzhou, and the overall urban planning map of Hangzhou (2001-2020) were used as the reference data for land use classification. Based on the national classification system of land resources of China (Land use status classification GB/T21010-2007) (National Standardization Administration Committee of China 2007) and the land classification of Zhejiang Province (for the transitional period), the land use type of the study area was divided into five categories—urban land, forestry land, arable land, grassland, and water body, respectively. Urban lands refer to the lands that are covered by buildings or other impervious surfaces; forestry land is vegetation dominated by woody plants; arable lands are the lands used for agricultural production; grassland refers to vegetation dominated by herbaceous plants on terrestrial land; and, water bodies refer to rivers, lakes, and wetlands.

\section{Results}

\subsection{Change in Land Use/Cover from 2000 to 2010}

It was found that the land use pattern in Hangzhou underwent dramatic changes from 2000 to 2010. The area of changed land use reached $5569.1 \mathrm{~km}^{2}$, accounting for $33.6 \%$ of the total area of the study area. The proportion was $66.4 \%$, which was the ratio of the unchanged land area from 2000 and 2010 to the total land area of the study area. The types of land use that had changed were mainly urban land, arable land, and grassland, which accounted for $92.7 \%$ of the total changes $(43.4 \%, 42.3 \%$, and $7.0 \%$, respectively). Until 2010, the main type of land use in Hangzhou was that of urban land, with an increase rate of up to $94.6 \%$. The relative reduction of arable land area was comparatively fast and the reduction rate was $37.8 \%$. The change rate of water area was only $1.7 \%$ (Table 1 ). It can be seen that arable land and urban land were the most dramatically changed land use coverage types, and the severe loss of arable land accompanied the rapid urbanization process in Hangzhou. 
Table 1. The land use transformations in the study area from 2000 to 2010.

\begin{tabular}{ccc}
\hline Land Use Form & Area $\left.\mathbf{( k m}^{\mathbf{2}}\right)$ Proportion $\mathbf{( \% )}$ & Conversion Rate $\mathbf{( \% )}$ \\
\hline Urban land & $2418.5 / 14.6$ & 94.6 \\
Arable land & $2357.4 / 14.2$ & 37.8 \\
Forestry land & $366.0 / 2.2$ & 7.4 \\
Water body & $40.0 / 0.2$ & 1.7 \\
Grassland & $387.2 / 2.3$ & 70.1 \\
Total & $5569.1 / 33.6$ & 211.6 \\
\hline
\end{tabular}

Note: Area is the changed land area from 2000 to 2010. Proportion is the percentage of the changed land area to the total land area of the whole study area. Conversion rate is the ratio of the changed land area to the land area of the same land use in 2000.

Only the area of urban land in region $\mathrm{M}$ increased, with a total increase of $151.4 \mathrm{~km}^{2}$, equivalent to an increase of $21.5 \%$, as shown in Table 2 . The remaining four land types in region $\mathrm{M}$ reduced in area. Among them, the land type with the largest area reduction was arable land, reaching $113.2 \mathrm{~km}^{2}$, which was equivalent to a decrease of $67.1 \%$. The change in land use type in region $\mathrm{V}$ was similar to that in region $\mathrm{M}$.

While urban land was increased, the areas of arable land, grassland, and water bodies were reduced in the sub-urban region $(\mathrm{V})$. Additionally, the area of the forestry land increased by $1.0 \mathrm{~km}^{2}$ in the sub-urban region, which was different from the core urban region $(\mathrm{M})$. The change in land use type of the rural urban region $(\mathrm{G})$ was consistent with that of region $V$, where the urban and forestry land areas were increased in the sub-urban and rural urban regions. In general, the areas of arable land and grassland in the three areas sharply declined, while the area of urban city significantly increased and it became the main type of urban land use in Hangzhou.

Table 2. Land use changes from 2000 to 2010 in three regions of Hangzhou City.

\begin{tabular}{cccccc}
\hline \multirow{2}{*}{ Region } & \multicolumn{5}{c}{ Area $\left(\mathbf{k m}^{2}\right) /$ Proportion $\mathbf{( \% )}$} \\
\cline { 2 - 6 } & Urban Land & Arable Land & Forest Land & Water Body & Grassland \\
\hline M & $151.4 / 21.5$ & $113.2 / 67.1$ & $2.4 / 4.9$ & $3.8 / 7.7$ & $20.0 / 91.5$ \\
V & $419.8 / 55.9$ & $378.6 / 52.7$ & $1.0 / 1.4$ & $12.3 / 15.9$ & $51.8 / 86.8$ \\
G & $274.5 / 110.7$ & $333.0 / 42.5$ & $9.4 / 5.7$ & $33.8 / 26.2$ & $62.3 / 76.2$ \\
Total & $845.7 / 49.7$ & $824.8 / 49.4$ & $8.0 / 2.8$ & $49.9 / 19.5$ & $134.1 / 82.1$ \\
\hline
\end{tabular}

Note: For a specific land use in one region, the number before the slash indicates increasing or decreasing area from 2000 to 2010, and the number after the slash refers to the proportion of changed area relative to the area in 2000. M, the major city; V, the vice cities, including Jiangnan, Xiasha, and Linping; G, groups, including Linpu, Guali, Yipeng, Yuhang, Liangzhu, and Tangxi.

\subsection{Ruderal Species Diversity Characteristics}

\subsubsection{Ruderal Species Composition}

Two hundred and thirteen ruderal species, which belonged to 52 families and 157 genera, were recorded in the 1665 quadrats (Table 3). Among the 52 families, the largest were Compositae and Gramineae, including 23 genera and 28 species, accounting for $29.3 \%$ of the total genera and $26.3 \%$ of the total species, respectively, and that were the main group compositions of urban ruderals in Hangzhou. The high proportion of the Mesotypic (e.g., Scrophulariaceae, Labiatae, and Umbelliferae) with 5-14 species was an important component of ruderal flora, involving 57 genera and 96 species. In addition, 19 families (e.g., Plantaginaceae, Aizoaceae, and Caprifoliaceae) with one species made up the largest number of families, accounting for $36.5 \%$ of the total families. 
Table 3. Number of species composition of ruderals in the urban of Hangzhou.

\begin{tabular}{|c|c|c|c|c|}
\hline \multirow{2}{*}{ Category } & \multirow{2}{*}{ Number } & \multirow{2}{*}{ Family } & \multicolumn{2}{|c|}{ Number/Proportion (\%) } \\
\hline & & & Genera & Species \\
\hline \multirow[t]{2}{*}{ Plurimotypic } & 1 & Gramineae & $23 / 14.6$ & $28 / 13.1$ \\
\hline & 2 & Compositae & $23 / 14.6$ & 28/13.1 \\
\hline \multirow{15}{*}{ Mesotypic } & 3 & Scrophulariaceae & $3 / 1.9$ & $10 / 4.7$ \\
\hline & 4 & Labiatae & $7 / 4.5$ & $8 / 3.8$ \\
\hline & 5 & Umbelliferae & $6 / 3.8$ & $7 / 3.3$ \\
\hline & 6 & Caryophyllaceae & $5 / 3.2$ & $7 / 3.3$ \\
\hline & 7 & Rubiaceae & $3 / 1.9$ & $7 / 3.3$ \\
\hline & 8 & Polygonaceae & $2 / 1.3$ & $7 / 3.3$ \\
\hline & 9 & Rosaceae & $5 / 3.2$ & $6 / 2.8$ \\
\hline & 10 & Convolvulaceae & $5 / 3.2$ & $6 / 2.8$ \\
\hline & 11 & Amaranthaceae & $3 / 1.9$ & $6 / 2.8$ \\
\hline & 12 & Primulaceae & $2 / 1.3$ & $6 / 2.8$ \\
\hline & 13 & Violaceae & $1 / 0.6$ & $6 / 2.8$ \\
\hline & 14 & Leguminosae & $5 / 3.2$ & $5 / 2.3$ \\
\hline & 15 & Boraginaceae & $5 / 3.2$ & $5 / 2.3$ \\
\hline & 16 & Cyperaceae & $3 / 1.9$ & $5 / 2.3$ \\
\hline & 17 & Euphorbiaceae & $2 / 1.3$ & $5 / 2.3$ \\
\hline \multirow[t]{16}{*}{ Oligotypic } & 18 & Liliaceae & $4 / 2.5$ & $4 / 1.9$ \\
\hline & 19 & Cruciferae & $4 / 2.5$ & $4 / 1.9$ \\
\hline & 20 & Ranunculaceae & $2 / 1.3$ & $4 / 1.9$ \\
\hline & 21 & Araceae & $3 / 1.9$ & $3 / 1.4$ \\
\hline & 22 & Apocynaceae & $2 / 1.3$ & $3 / 1.4$ \\
\hline & 23 & Chenopodiaceae & $2 / 1.3$ & $3 / 1.4$ \\
\hline & 24 & Oxalidaceae & $1 / 0.6$ & $3 / 1.4$ \\
\hline & 25 & Acanthaceae & $2 / 1.3$ & $2 / 0.9$ \\
\hline & 26 & Cueurbitaceae & $2 / 1.3$ & $2 / 0.9$ \\
\hline & 27 & Portulacaceae & $2 / 1.3$ & $2 / 0.9$ \\
\hline & 28 & Crassulaceae & $2 / 1.3$ & $2 / 0.9$ \\
\hline & 29 & Vitaceae & $2 / 1.3$ & $2 / 0.9$ \\
\hline & 30 & Lythraceae & $2 / 1.3$ & $2 / 0.9$ \\
\hline & 31 & Solanaceae & $2 / 1.3$ & $2 / 0.9$ \\
\hline & 32 & Urticaceae & $2 / 1.3$ & $2 / 0.9$ \\
\hline & 33 & Callitrichaceae & $1 / 0.6$ & $2 / 0.9$ \\
\hline \multirow[t]{19}{*}{ Monotypic } & 34 & Plantaginaceae & $1 / 0.6$ & $1 / 0.5$ \\
\hline & 35 & Dryopteridaceae & $1 / 0.6$ & $1 / 0.5$ \\
\hline & 36 & Lygodiaceae & $1 / 0.6$ & $1 / 0.5$ \\
\hline & 37 & Orchidaceae & $1 / 0.6$ & $1 / 0.5$ \\
\hline & 38 & Menispermaceae & $1 / 0.6$ & $1 / 0.5$ \\
\hline & 39 & Geraniaceae & $1 / 0.6$ & $1 / 0.5$ \\
\hline & 40 & Pteridaceae & $1 / 0.6$ & $1 / 0.5$ \\
\hline & 41 & Equisetaceae & $1 / 0.6$ & $1 / 0.5$ \\
\hline & 42 & Saxifragaceae & $1 / 0.6$ & $1 / 0.5$ \\
\hline & 43 & Aizoaceae & $1 / 0.6$ & $1 / 0.5$ \\
\hline & 44 & Ophioglossaceae & $1 / 0.6$ & $1 / 0.5$ \\
\hline & 45 & Caprifoliaceae & $1 / 0.6$ & $1 / 0.5$ \\
\hline & 46 & Dioscoreaceae & $1 / 0.6$ & $1 / 0.5$ \\
\hline & 47 & Saururaceae & $1 / 0.6$ & $1 / 0.5$ \\
\hline & 48 & Moraceae & $1 / 0.6$ & $1 / 0.5$ \\
\hline & 49 & Commelinaceae & $1 / 0.6$ & $1 / 0.5$ \\
\hline & 50 & Phytolaccaceae & $1 / 0.6$ & $1 / 0.5$ \\
\hline & 51 & Amaryllidaceae & $1 / 0.6$ & $1 / 0.5$ \\
\hline & 52 & Araliaceae & $1 / 0.6$ & $1 / 0.5$ \\
\hline
\end{tabular}

Note: Species composition of ruderals in the urban land of Hangzhou was divided into four categories according to the number of species in each family. Plurimotypic: Family with more than 14 species; Mesotypic: Family with 5-14 species; Oligotypic: Family with 2-4 species; Monotypic: Family with one species. 


\subsubsection{Areal Type of Families and Genera of Ruderals}

Species could be divided into six distribution types at the family level. The cosmopolitan types had the highest number (30 families) and they accounted for $57.7 \%$ of the total number of families. In addition to cosmopolitan types, tropical distribution (all of the 2nd-7th areal types in Table 4) was significantly higher than temperate distribution (all of the 8th-14th areal types in Table 4), with pantropical distribution (15 families) accounting for the highest at $68.2 \%$.

At the genera level, species could be divided into 14 distribution types (as well as endemic distribution in China). Among them, 33 genera were distributed worldwide, accounting for $21.0 \%$ of the total. Topical ruderals had similar proportions to the genera of the temperate geographical components, except for world distribution. Moreover, there were also two endemic species in China, namely, Omphalotrigonotis cupulifera and Sinojohnstonia plantaginea.

Table 4. Areal type of genera of ruderals in the urban of Hangzhou.

\begin{tabular}{ccc}
\hline Type & Areal Type & $\mathbf{N} / \%$ \\
\hline Cosmopolitan & 1 Cosmopolitan & $33 /-$ \\
Tropical ruderal & 2 Pantropic & $41 / 33.1$ \\
& 3 Tropical Asia and Tropical America Disjuncted & $3 / 2.4$ \\
& 4 Old World Tropics & $5 / 4.0$ \\
& 5 Tropical Asia to Tropical Australiasia & $2 / 1.6$ \\
& 6 Tropical Asia to Tropical Africa & $2 / 1.6$ \\
Temperate ruderal & 7 Tropical Asia (Indo-Malesia) & $6 / 4.9$ \\
& 8 North temperate & $31 / 25.0$ \\
& 9 East Asia \& North America Disjuncted & $2 / 1.6$ \\
& 10 Old World Temperate & $12 / 9.7$ \\
Total & 11 Temperate Asia & $2 / 1.6$ \\
& 12 Mediterranea, West Asia to Central Asia & $2 / 1.6$ \\
& 14 East Asia & $14 / 11.3$ \\
\end{tabular}

\subsubsection{Life Form and Growth Form}

Summer annual and perennial types dominated the life form of urban ruderal species in Hangzhou. Among the 213 ruderals surveyed, 110 (51.6\%) were annual species and 103 (48.4\%) were perennial species, as shown in Table 5 . The annual ruderals were further divided into 81 summer annual species and 29 winter annual species, accounting for $38.0 \%$ and $13.6 \%$ of the total, respectively. Among the perennial ruderals, hemicryptophyte species accounted for the majority ( $27.7 \%$ of the total).

The dominant ruderal growth form was small growth form. Small growth form contained 133 species, accounting for $62.4 \%$, as shown in Table 5. Among them, the branched type (35 species) was the most abundant. The tussock and the procumbent types were second in abundance, containing 32 species. The rosette type contained the least species (only nine species). In the large growth species, the erect type (45 species) accounted for the highest proportion (21.1\%). 
Table 5. Life form and growth form composition of ruderal species in the urban of Hangzhou.

\begin{tabular}{cccc}
\hline & Species Type & Number/Proportion(\%) \\
\hline \multirow{2}{*}{ Life form } & Annual species & Summer annual & $81 / 38.0$ \\
& & Winter annual & $29 / 13.6$ \\
\cline { 2 - 4 } & Perennial species & Geophyte & $23 / 10.8$ \\
& & Hemicryptophyte & $59 / 27.7$ \\
& & Chamaephyte & $21 / 9.9$ \\
\hline \multirow{3}{*}{ Growth form } & Brall growth form & Climbing or liane & $35 / 16.4$ \\
& & Procumbent & $25 / 11.7$ \\
& & Rosette & $32 / 15.0$ \\
& & Tussock & $9 / 4.2$ \\
& & Erect & $32 / 15.0$ \\
& & Partial rosette & $45 / 21.1$ \\
& & Pseudo-rosette & $17 / 8.0$ \\
& & & $18 / 8.5$ \\
\hline
\end{tabular}

\subsection{Distribution Pattern of Ruderal Community on Urbanization Gradient}

\subsubsection{Ruderal Community Type}

Cluster analysis was performed by the dominance of ruderal species based on the survey data of ruderal samples in the $\mathrm{M}, \mathrm{V}$, and $\mathrm{G}$ regions. The ruderal communities in the three regions were divided into 125 community types (Table A1). The community types with a frequency of more than 70 samples were ranked from high to low in the order of Digitaria sanguinalis community (125) $>$ Ophiopogon japonicus community (113) > Alternanthera philoxeroides community (107) $>$ Stellaria media community (87) > Erigeron philadelphicus community (79) > Cynodon dactylon community (73). In addition, 35 communities, including Omphalotrigonotis cupulifera community, Mosla scabra community, Siegesbeckia glabrescens community, and Polygonum perfoliatum community, only appeared in one sample.

The number of ruderal community types was shown to be non-linear, decreasing from the low urbanization region $(\mathrm{V})$ to the high urbanization region $(\mathrm{M})$, ranking from large to small as $\mathrm{V}(94)>$ $\mathrm{G}(91)>M(51)$. The number of ruderal communities in the suburban (V) and rural (G) regions were similar, but higher than those for the urban center $(\mathrm{M})$ region.

\subsubsection{Dominant Species Characteristics}

The proportions of dominant ruderal species with annual life form and with perennial life form in region $\mathrm{M}$ were $60.8 \%$ and $39.2 \%$, respectively. The proportions of summer annual species were $21.6 \%$ more than those of the winter annual species. The dominant species in region $\mathrm{G}$ were mainly of annual life form (57.1\%), of which the proportions of summer annual species accounted for $38.4 \%$ (Figure 2). The distribution of the dominant species in region $\mathrm{V}$ was the similar as that in region $\mathrm{G}$. In region M, the proportions of annual species were the highest and the proportions of perennials were the lowest. 


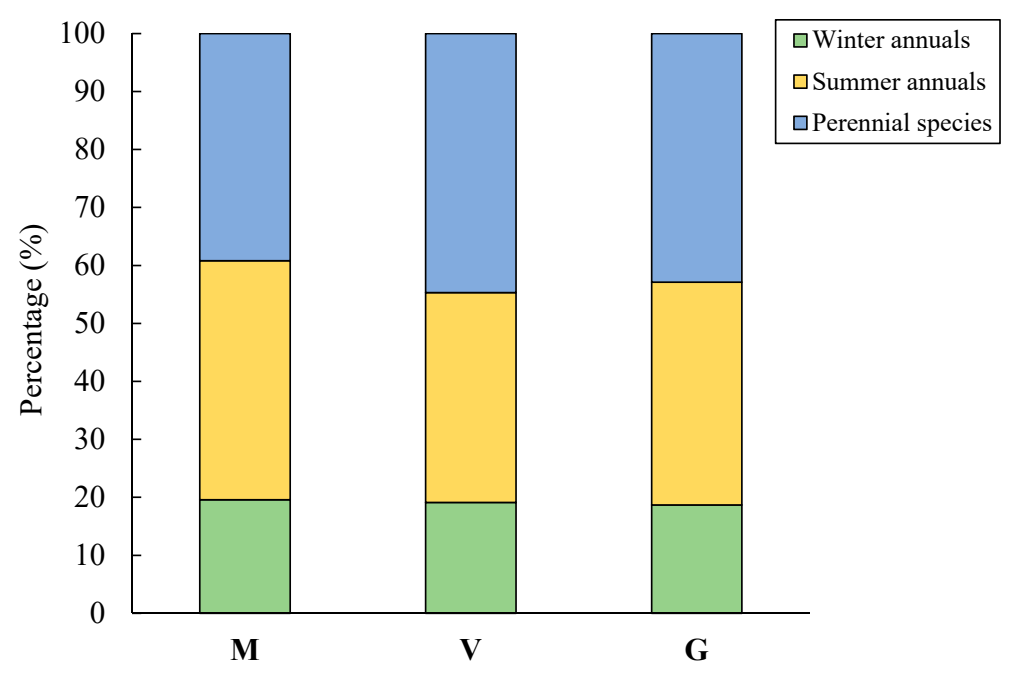

Figure 2. Life form composition of the dominant species.

The number of dominant ruderal species with small growth forms (tussock, rosette, procumbent, climbing or liane, and branched) was greater than that of large growth forms (pseudo-rosette, partial rosette, and erect) in the three areas (Figure 3). The proportions of dominant species with small growth forms in regions $\mathrm{M}, \mathrm{V}$, and $\mathrm{G}$ were $62.7 \%, 63.8 \%$, and $58.2 \%$, respectively. These species included Galium aparine, Humulus scandens, and Stellaria media. The proportions of the branched and erect growth form in regions $\mathrm{M}$ and $\mathrm{V}$ were the highest, which were $19.6 \%$ and $17.0 \%$, respectively. Erect was the growth form with the highest proportion in region $\mathrm{G}(22.0 \%)$. The rosette growth form accounted for the smallest proportion in the three areas $(2.0 \%, 2.1 \%$, and $2.2 \%$, respectively).

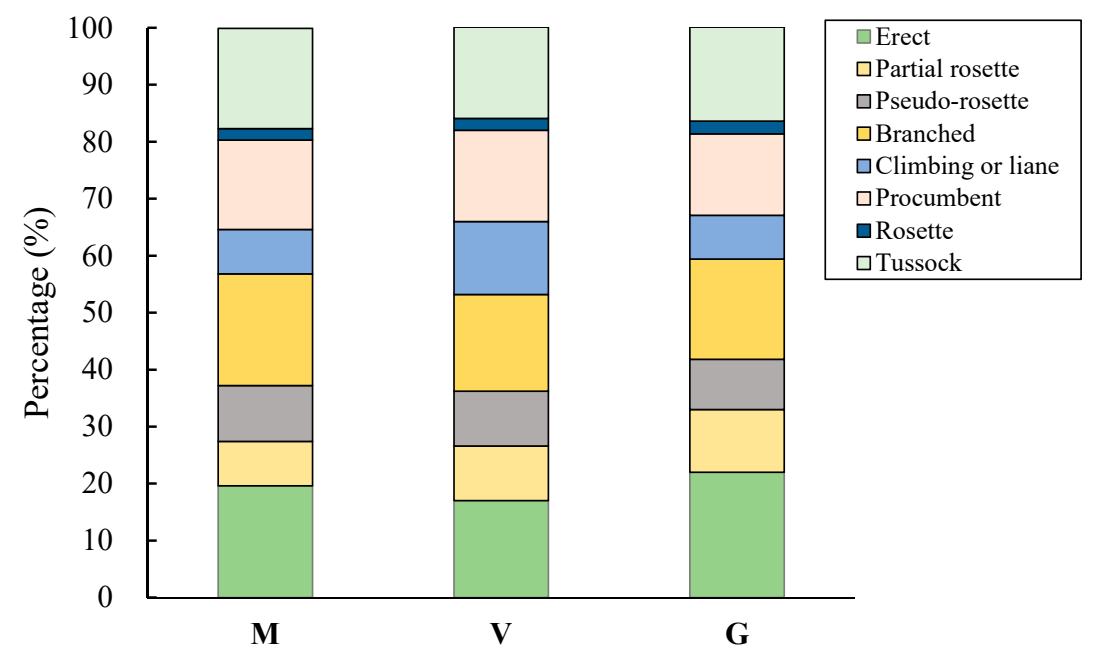

Figure 3. Growth form composition of the dominant species.

Tropical distribution of the community dominant species were the major type in regions $\mathrm{M}, \mathrm{V}$, and G, accounting for $41.2 \%, 36.2 \%$, and $38.5 \%$, respectively (Figure 4 ). The distribution area types of the dominant species were consistent and the proportion from high to low was tropical, temperate, and cosmopolitan in regions $\mathrm{V}$ and $\mathrm{G}$. 


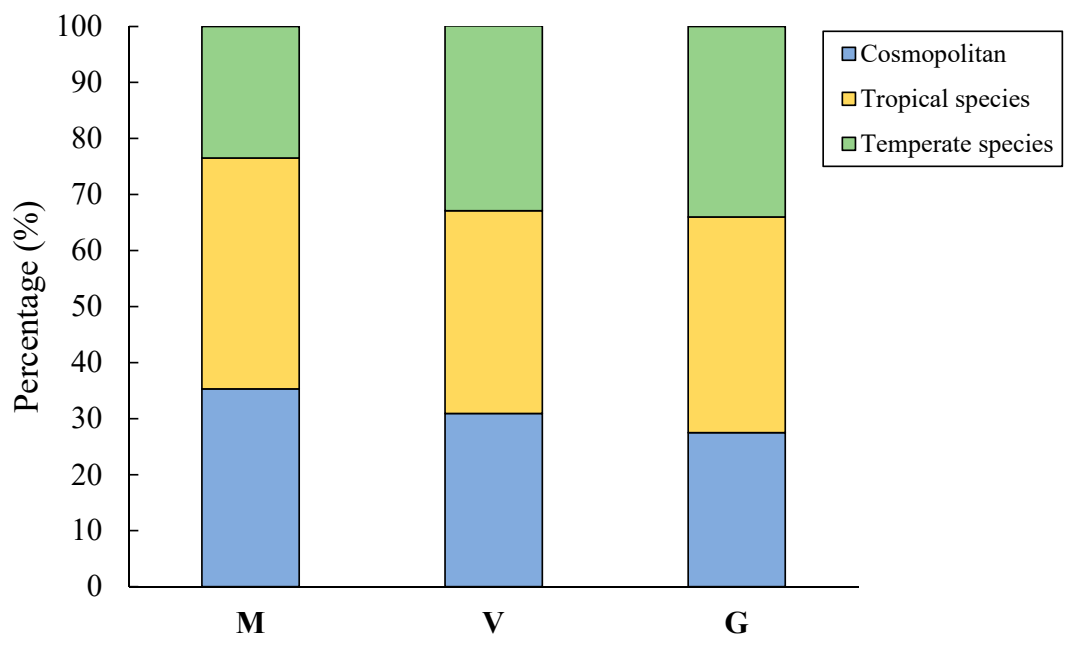

Figure 4. Distribution area type of the dominant species.

\subsubsection{Ruderal Community Diversity}

The diversity of ruderal communities was analyzed in different areas (Figure 5). It was found that the richness index of the communities in different areas was same $(\mathrm{F}=1.751, p=0.174)$, with a mean value of approximately 7.0. It can be seen that at least one species occurred in each quadrat in each of the areas, according to the minimum and maximum values of species richness. The largest number of species that was found was in region $\mathrm{G}$, which was 17 species in all three sampling quadrats.

(A)

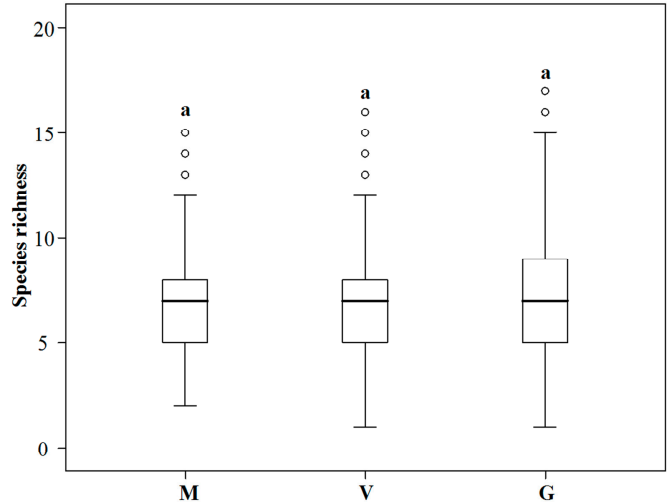

(B)

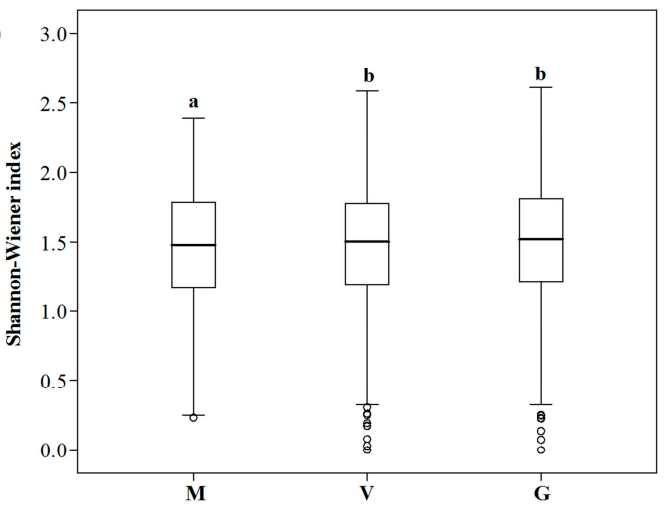

Figure 5. (A) Species richness and (B) the Shannon-Wiener index of ruderal communities in different zones. Note: The three horizontal lines.in the box diagram represent the lower quartile (25\%), the median (50\%), and the upper quartile (75\%) from bottom to top. The open circles represent outliers; the different letters $\mathrm{a}$ and $\mathrm{b}$ indicate that there are significant $(p<0.05)$ differences (one-way ANOVA with post-hoc Tukey HSD test).

The mean values of the Shannon-Wiener index were consistent with the species richness. The largest value occurred in region $\mathrm{G}$, with an average of 1.50. Regions $\mathrm{V}$ and $\mathrm{M}$, with averages of 1.45 and 1.43, respectively, followed this. Significant differences were found in species diversity between regions $\mathrm{M}$ and $\mathrm{V}$ or $\mathrm{G}(\mathrm{F}=3.102, p=0.045)$. There was no significant difference in the species diversity between regions $\mathrm{V}$ and $\mathrm{G}$.

\section{Discussion}

\subsection{Impact of Urbanization Process on Ruderal Species Diversity}

Urbanization has resulted in a dramatic impact on urban environment $[46,47]$, which has created changes in urban species diversity [48,49]. By comparing the land use patterns of Hangzhou in 2000 
and 2010, this study found that arable land and urban land were the most rapidly changing types of land use cover. Urban land has become the main type of land use in Hangzhou, and the rapid expansion of the city has been at the expense of a large number of important natural landscapes, such as arable land and grassland. The area of arable land decreased by $2357.4 \mathrm{~km}^{2}$ during these 10 years, and the grassland change rate was as high as $70.1 \%$. The intensification of human disturbance in the process of urbanization has made urban habitats more volatile, which results in a gradual reduction in the space available for ruderals to survive and grow.

The rapid urbanization process has affected not only the environment on which vegetation depends [50-52], but also the composition and diversity of urban vegetation species [53-56]. This study found that the Gramineae and Compositae species are the main groups of ruderals in Hangzhou, which reflects the characteristics of a few large families. This is similar to the results of related studies on the composition of urban vegetation in Central Europe and China's Kunming, Beijing, Shanghai, and other places [25,57-60]. The number of families of monotypic and oligotypic are higher than that of plurimotypic and mesotypic, accounting for $67.3 \%$ of the total. Among the 157 genera, Viola, Lindernia, Lysimachia, and Polygonum have the highest number of species. The proportion of single species genera (126) is as high as $80.3 \%$, which indicates that the composition of ruderal species in this flora is relatively complex, and the species diversity index is high.

The proportion of annual species in the urban ruderals of Hangzhou (51.6\%) was slightly higher than that of perennials $(48.4 \%)$, and the annual life form of summer $(38.0 \%)$ was higher than that of winter (13.6\%). Moreover, the proportion of annual ruderals in the dominant species of ruderal communities decreased from the central urban area $(\mathrm{M})$ to the sub-city area $(\mathrm{V})$ and the group area $(G)$; the percentage of dominated perennials in region $M$ was the lowest. The reason may be that the urbanization process has caused a reduction of the stable natural habitats. This has resulted in perennial ruderals that can only grow in relatively stable habitats having largely disappeared due to their inability to evolve from annual succession to the perennial stage [6,61]. Annual ruderals have taken advantage of biological characteristics, such as short-life history cycles, low plants, and cormorant growth, to minimize the impact of human disturbance and maintain normal reproduction and proliferation ability and, thus, survive in large numbers. This is similar to the results of the Flora study in Shanghai [41].

The number of cosmopolitan distribution families (30 families) was the largest among the urban ruderals in Hangzhou. In addition, the proportion of tropical species was higher than the proportion of temperate species. The emergence of a large number of widely distributed species with high tolerance and plasticity was a response of ruderals to urban habitats under strong human disturbance $[30,41]$. The proportions of genera and species in temperate distribution were similar to those in tropical distribution. The reason might be related to the geographical location and climatic factors of Hangzhou, as Hangzhou belongs to the mid-subtropical monsoon climate, with distinct temperate and subtropical East Asian flora features, and tropical and temperate species thus coexist.

\subsection{Causes of Ruderal Community Diversity}

Among the 213 ruderal species that were surveyed in this study, there were 125 community types, which accounted for the $58.7 \%$ of the total number species recorded in the study. This shows that the types of ruderal communities in Hangzhou are rich. The reason may be the transformation of land use caused by the process of urbanization, resulting in the production of heterogeneous urban habitats, thus forming a diverse regional micro-habitat for species with different ecological habits [62].

The reduction of number of community types from groups $(G)$ to central urban area $(M)$ are also linked with natural habitats shrinking that is caused by land use changes $[18,63,64]$. Especially, in an urbanized area, the shrunk habitats are isolated with each other and plants in these habitats are under high disturbance stress. Islandized habitats are not conducive to the spread of pollen and seeds, which thus cause genetic decline and even extinction in many species $[65,66]$. Furthermore, any potential human-caused disturbance can significantly change the habitat quality via the cascading effects on 
biophysical structure and function [67]. Only a few plants can cope with different forms of disturbance, and plant with high dispersal ability and smaller growth forms usually become dominant species in severe disturbed urban area [68,69], which was also found in our study that small growth forms has greater a percentage in higher urbanization regions. Thus the community types were fewer in the center of urban. On the contrary, regions V and G had relatively low levels of human disturbance and natural landscape damage, resulting diverse habitat types that can support plants of different ecological habits [62]. Thus, there were more types of ruderal communities in regions V and G.

The present analysis found that the proportion of ruderal communities in single dominant species is high in Hangzhou. The reason is mainly related to the fact that ruderals often undergo asexual propagation by rhizomes or sexual propagation by granular seeds [44]. The rhizomes of ruderals are potentially independent, can maintain a constantly updated state in urban habitats with severe human disturbance, and they can occupy large areas of habitat and form communities. Moreover, they hinder the survival of other species, thus forming a single dominant species community [41,69]. Wind transmission can also sexually propagate the granular seeds of ruderals. However, due to the relatively closed urban habitat, many of them grow in the vicinity of the mother plants to form a community [2,41]. The diversity characteristics of urban ruderal communities in Hangzhou are consistent with those in Shanghai, where ruderals, due to their strong adaptability and high plasticity, can form diverse communities in heterogeneous habitats that are caused by high-frequency human disturbance [70].

\section{Conclusions}

As a part of urban biodiversity, ruderal vegetation has a certain degree of practical value, i.e. using for wilding flower lawn, natural vegetable food. The present study focused on the distribution pattern of ruderal communities under rapid urbanization in Hangzhou, China. We found that ruderal diversity decreased from the rural region $(\mathrm{G})$ to central urban area $(\mathrm{M})$, covaried with increasing urban lands and decreasing natural lands. Ruderal species with shorter life span and smaller size become more dominant in high urbanized areas. These suggested urbanization working on ruderal species as an environmental seize, filtering natural habitats that favor long-time life and taller ruderal species. We suggest that other mechanisms, i.e. habitat fragmentation, should also contribute to the patterns found in this study, which need further study under patch-matrix landscape framework.

Author Contributions: Conceptualization and Methodology, L.D. and K.S.; Data curation, M.Z.; Formal analysis, M.Z. and K.S.; Funding acquisition, L.D.; Writing-original draft, M.Z.; Writing-review \& editing, L.D. and K.S. All authors have read and agreed to the published version of the manuscript.

Funding: This research was funded by the National Natural Science Foundation of China (No. 31770468), the Ministry of Science and Technology of China (2015FY210200-4), the Shanghai Key Lab for Urban Ecological Processes and Eco-Restoration.

Acknowledgments: The authors are grateful to Cui Yichong and Zhang Xijin for the constructive comments and suggestions. Special thanks are extended to the editors and the anonymous reviewers for their valuable comments.

Conflicts of Interest: The authors declare no conflicts of interest. 


\section{Appendix A}

\section{Appendix A.1}

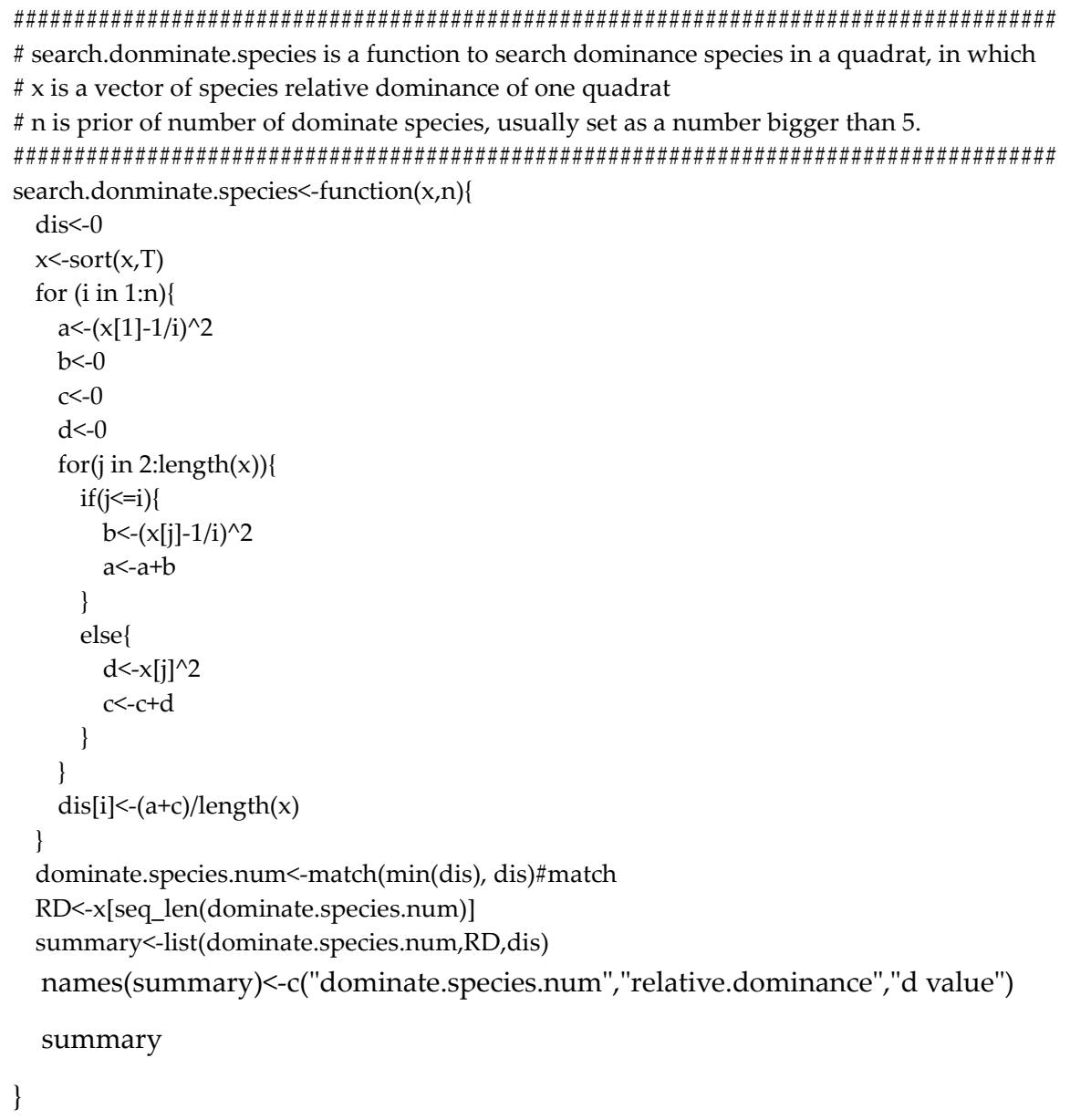

Figure A1. R codes.

Appendix A.2

Table A1. 125 types of ruderal communities in the urban of Hangzhou.

\begin{tabular}{cccc}
\hline Number & Community Name & Number & Community Name \\
\hline 1 & Acalypha australis comm. & 64 & Lithospermum zollingeri comm. \\
2 & Achyranthes bidentate comm. & 65 & Lolium perenne comm. \\
3 & Alopecurus aequalis comm. & 66 & Lygodium japonicum comm. \\
4 & Alternanthera philoxeroides comm. & 67 & Lysimachia candida comm. \\
5 & Amaranthus retroflexus comm. & 68 & Lysimachia fortune comm. \\
6 & Amaranthus tricolor comm. & 69 & Lysimachia pentapetala comm. \\
7 & Ammannia baccifera comm. & 70 & Mazus japonicus comm. \\
8 & Artemisia argyi comm. & 71 & Mentha haplocalyx comm. \\
9 & Arthraxon hispidus comm. & 72 & Mosla scabra comm. \\
10 & Aster subulatus comm. & 73 & Myosoton aquaticum comm. \\
\hline
\end{tabular}


Table A1. Cont.

\begin{tabular}{|c|c|c|c|}
\hline Number & Community Name & Number & Community Name \\
\hline 11 & Bidens frondosa comm. & 74 & Oenanthe javanica comm. \\
\hline 12 & Callitriche stagnalis comm. & 75 & Omphalotrigonotis cupulifera comm. \\
\hline 13 & Calystegia hederacea comm. & 76 & Ophioglossum vulgatum comm. \\
\hline 14 & Capsella bursa-pastoris comm. & 77 & Ophiopogon japonicas comm. \\
\hline 15 & Cardamine hirsuia comm. & 78 & Oplismenus undulatifolius comm. \\
\hline 16 & Carpesium abrotanoides comm. & 79 & Oxalis corniculata comm. \\
\hline 17 & Cayratia japonica comm. & 80 & Paederia scandens comm. \\
\hline 18 & Centipeda minima comm. & 81 & Pennisetum alopecuroides comm. \\
\hline 18 & Cerastium arvense comm. & 82 & Phytolacca acinosa comm. \\
\hline 20 & Cerastium glomeratum comm. & 83 & Pinellia ternate comm. \\
\hline 21 & Chenopodium glaucum comm. & 84 & Plantago asiatica comm. \\
\hline 22 & Commelina communis comm. & 85 & Роа аппиа соmm. \\
\hline 23 & Conyza Canadensis comm. & 86 & Polygonum aviculare comm. \\
\hline 24 & Coreopsis drummondii comm. & 87 & Polygonum hydropiper comm. \\
\hline 25 & Cynodon dactylon comm. & 88 & Polygonum lapathifolium comm. \\
\hline 26 & Cyperus brevifolia comm. & 89 & Polygonum perfoliatum comm. \\
\hline 27 & Cyperus compressus comm. & 90 & Polygonum persicaria comm. \\
\hline 28 & Daucus carota comm. & 91 & Polypogon fugax comm. \\
\hline 29 & Dichondra repens comm. & 92 & Porana racemose comm. \\
\hline 30 & Digitaria sanguinalis comm. & 93 & Portulaca oleracea comm. \\
\hline 31 & Dryopteris chinensis comm. & 94 & Pouzolzia zeylanica comm. \\
\hline 32 & Duchesnea indica comm. & 95 & Pterocypsela indica comm. \\
\hline 33 & Echinochloa crusgalli comm. & 96 & Ranunculus sceleratus comm. \\
\hline 34 & Eclipta prostrata comm. & 97 & Reineckia carnea comm. \\
\hline 35 & Eleusine indica comm. & 98 & Roegneria kamoji comm. \\
\hline 36 & Equisetum hyemale comm. & 99 & Rorippa indica comm. \\
\hline 37 & Eragrostis ferruginea comm. & 100 & Rostellularia procumbens comm. \\
\hline 38 & Erigeron annuus comm. & 101 & Rumex dentatus comm. \\
\hline 39 & Erigeron philadelphicus comm. & 102 & Rumex japonicas comm. \\
\hline 40 & Eriochloa villosa comm. & 103 & Sagina japonica comm. \\
\hline 41 & Eryngium foetidum comm. & 104 & Sambucus chinensis comm. \\
\hline 42 & Euphorbia hirta comm. & 105 & Saxifraga stolonifera comm. \\
\hline 43 & Calystegia hederacea comm. & 106 & Sedum emarginatum comm. \\
\hline 44 & Euphorbia maculate comm. & 107 & Sedum quaternatum comm. \\
\hline 45 & Festuca elata comm. & 108 & Setaria viridis comm. \\
\hline 46 & Foeniculum vulgare comm. & 109 & Siegesbeckia glabrescens comm. \\
\hline 47 & Fragaria vesca comm. & 110 & Solanum nigrum comm. \\
\hline 48 & Galium aparine comm. & 111 & Solidago canadensis comm. \\
\hline 49 & Galium bungei comm. & 112 & Sonchus oleraceus comm. \\
\hline 50 & Geranium carolinianum comm. & 113 & Stellaria media comm. \\
\hline 51 & Glechoma longituba comm. & 114 & Talinum paniculatum comm. \\
\hline 52 & Glycine soja comm. & 115 & Taraxacum mongolicum comm. \\
\hline 53 & Gnaphalium affine comm. & 116 & Trachelospermum jasminoides comm. \\
\hline 54 & Hedera nepalensis var. Sinensis comm. & 117 & Trifolium repens comm. \\
\hline 55 & Hemistepta lyrata comm. & 118 & Trigonotis peduncularis comm. \\
\hline 56 & Humulus scandens comm. & 119 & Veronica didyma comm. \\
\hline 57 & Hydrocotyle sibthorpioides comm. & 120 & Vicia sepium comm. \\
\hline 58 & $\begin{array}{l}\text { Hydrocotyle sibthorpioides var. } \\
\text { batrachium comm. }\end{array}$ & 121 & Vinca major comm. \\
\hline 59 & Ixeris sonchifolia comm. & 122 & Viola betonicifolia comm. \\
\hline 60 & Kalimeris indica comm. & 123 & Viola diffusa comm. \\
\hline 61 & Leptochloa chinensis comm. & 124 & Youngia japonica comm. \\
\hline 62 & Lindernia nummularifolia comm. & 125 & Zephyranthes candida comm. \\
\hline 63 & Liriope platyphylla comm. & & \\
\hline
\end{tabular}




\section{References}

1. Burghardt, W. Soil sealing and soil properties related to sealing. Geol. Soc. Lond. Spec. Publ. 2006, 266, 117-124. [CrossRef]

2. Zhao, H.X.; Jiang, Y.; Liu, Q.R. Study of impact of urban land use on feature of urban vegetation in Beijing area. Adv. Earth Sci. 2002, 17, 247-253. (In Chinese)

3. Huang, L.Y.; Liu, S.H.; Li, J. Spatial and temporal dynamics of urban ecological land use and its related driving forces: A case study of Wuhan city. Resour. Environ. Yangtze Basin 2019, 28, 1059-1069. (In Chinese)

4. Sukopp, H. Human-caused impact on preserved vegetation. Landsc. Urban Plan. 2004, 68, 347-355. [CrossRef]

5. Zhao, S.Q.; Da, L.J.; Tang, Z.Y.; Fang, H.J.; Song, K.; Fang, J.Y. Ecological consequences of rapid urban expansion: Shanghai, China. Front. Ecol. Environ. 2006, 4, 341-346. [CrossRef]

6. Li, Y.Y. Study on Ruderal Community Diversity and Distribution under Different Land Use Type in Suburban of Shanghai. Master's Thesis, East China Normal University, Shanghai, China, 2009. (In Chinese).

7. Kowarik, I. The role of alien species in urban flora and vegetation. In Plant Invasions General Aspects and Special Problems; Pyšek, P., Ed.; SPB Academic: Amsterdam, The Netherlands, 1995; pp. 321-338.

8. Lu, Y.C. Theory and Practice of Close-to-Nature Forest Management; Science Press: Beijing, China, 2006. (In Chinese)

9. Wu, Y.X.; Zhu, X.; Liu, X.G.; Li, M.M.; Lu, M. Urban ecological network restoration based on landscape pattern analysis. Shanghai Urban Plan. Rev. 2019, 11, 40-44. (In Chinese)

10. Wang, B.S. Phytocoenostics; Higher Education Press: Beijing, China, 1987. (In Chinese)

11. Burton, M.L.; Samuelson, L.J.; Mackenzie, M.D. Riparian woody plant traits across an urban-rural land use gradient and implications for watershed function with urbanization. Landsc. Urban Plan. 2009, 90, 42-55. [CrossRef]

12. Zhang, L.J.; Cai, H.; Wang, X.W.; Guan, L.J.; Chen, G. Analysis the change of urban ecological environment in huaxi district of Guiyang. Geomat. Spat. Inf. Technol. 2019, 42, 50-57. (In Chinese)

13. Panitsa, M.; Iliadou, E.; Kokkoris, I.; Kallimanis, A.; Patelodimou1, C.; Strid, A.; Raus, T.; Bergmeier, E.; Dimopoulos, P. Distribution patterns of ruderal plant diversity in Greece. Biodivers. Conserv. 2019, 29, 869-891. [CrossRef]

14. Franceschi, E.A. The ruderal vegetation of Rosario City, Argentina. Landsc. Urban Plan. 1996, 34, 11-18. [CrossRef]

15. Anning, A.K.; Yeboah-Gyan, K. Diversity and distribution of invasive weeds in Ashanti Region, Ghana. Afr. J. Ecol. 2007, 45, 355-360. [CrossRef]

16. Rendeková, A.; Mičieta, K.; Hrabovský, M.; Eliašová, M.; Miškovic, J. Effects of invasive plant species on species diversity: Implications on ruderal vegetation in Bratislava City, Slovakia, Central Europe. History 2019, 88, 3621. [CrossRef]

17. Hitchmough, J.; Woudstra, J. The ecology of exotic herbaceous perennials grown in managed, native grassy vegetation in urban landscapes. Landsc. Urban Plan. 1999, 45, 107-121. [CrossRef]

18. Benvenuti, S. Weed dynamics in the Mediterranean urban ecosystem: Ecology, biodiversity and management. Weed Res. 2004, 44, 341-354. [CrossRef]

19. Rendeková, A.; Mičieta, K. Changes in the representation of alien taxa in ruderal vegetation of an urban ecosystem over 50 years. A case study from Malacky city, Slovakia, Central Europe. Urban Ecosyst. 2017, 20, 867-875. [CrossRef]

20. Whitney, G.G. A quantitative analysis of the flora and plant communities of a representative Midwestern UStown. Urban Ecol. 1985, 9, 143-160. [CrossRef]

21. Guo, P.P.; Yu, F.; Ren, Y.; Liu, D.; Li, J.; Ouyang, Z.Y.; Wang, X.K. Response of ruderal species diversity to an urban environment: Implications for conservation and management. Int. J. Environ. Res. Public Health 2018, 15, 2832. [CrossRef]

22. Sharpe, D.M.; Stearns, F.; Leitner, L.A.; Dorney, J.R. Fate of natural vegetation during urban development of rural landscapesin southeastern Wisconsin. Urban Ecol. 1986, 9, 267-287. [CrossRef]

23. Cilliers, S.S.; Bredenkamp, G. Vegetation of roadside verges on an urbanization gradient in Potchefstroom, South Africa. Landsc. Urban Plan. 2000, 46, 217-239. [CrossRef]

24. Cao, Y.; Natuhara, Y. Effect of urbanization on vegetation in riparian area: Plant communities in artificial and semi-natural habitats. Sustainability 2020, 12, 204. [CrossRef] 
25. Ou, X.K.; Yu, M. Urban vegetation and urban flora of Kunming China. Yunnan Univ. (Nat. Sci.) 1994, 16, 266-270. (In Chinese)

26. Yong, S.P.; Liu, S.R.; Na, R.S.; Ou, X.K. A Preliminary analysis and study on the urban flora and urban vegetation in Hohhot the city located in the grassland area of North China. Acta Sci. Nat. Univ. Neimongol 1999, 30, 206-213. (In Chinese)

27. Luo, W.; He, P.R.; Zhou, P.; Zhao, P.; Chen, J.W. Species composition and origin range of farmland weeds frequently observed in Kunming, Yunnan. Weed Sci. 2016, 34, 36-42. (In Chinese)

28. Wang, Z.R.; Duan, H.F.; Yang, J.D.; Guo, J.; Wang, S.H.; Li, J.; Gao, J.Y. Composition of weeds and its control measures in lemon orchard of hot and humid area in Yunnan. South China Agric. 2018, 12, 4-7. (In Chinese)

29. Zhang, B.; Chen, G.Q.; Yu, J.Y. Diversity of weeds in kiwifruit orchards in Guizhou. Southwest China J. Agric. Sci. 2019, 32, 360. (In Chinese)

30. Chen, X.S.; Wang, W.B.; Liang, H.; Liu, X.L.; Da, L. Dynamics of ruderal species diversity under the rapid urbanization over the past half century in Harbin, Northeast China. Urban Ecosyst. 2014, 17, 455-472. [CrossRef]

31. Ye, Y.D.; Liu, F.D.; Hu, G. Spatial pattern of forest vegetation in West Lake Scenic Area, Hangzhou. J. Zhejiang Sci.-Tech. Univ. 2019, 41, 407-412. (In Chinese)

32. Editorial Committee of Flora Repubicae Popularis Siniae in China Academy of Science. Flora of China; Science Press: Beijing, China, 2004; Volume 1. (In Chinese)

33. Editorial Committee of Flora of Zhejiang. Flora of Zhejiang, 1992-1993 ed.; Zhejiang Science and Teconology Publishing: Zhejiang, China, 1993; Volumes 1-7. (In Chinese)

34. Wang, L.; Liao, W.; Chen, C.; Fan, Q. The seed plant flora of the mount Jinggangshan Region, Southeastern China. PLoS ONE 2013, 88, e75834. [CrossRef]

35. Wu, Z.Y.; Zhou, Z.K.; Sun, H.; Li, D.Z.; Peng, H. The Areal-Types of Seed Plants and Their Origin and Differentiation; Yunnan Science and Technology Press: Kunming, China, 2006. (In Chinese)

36. Wu, Z.Y. China Vegetation; Science Press: Beijing, China, 1980. (In Chinese)

37. Zhang, Z.P.; Hirota, S. Chinese Colored Weed Illustrated Book; National Rural Education Association: Tokyo, Japan, 2000.

38. Song, Y.C. Vegetation Ecology; East China Normal University Press: Shanghai, China, 2001. (In Chinese)

39. Numata, M.; Yoshizawa, N. Weed Flora of Japan Illustrated by Color; Zenkoku Noson Kyoiku Kyokai: Tokyo, Japan, 1988.

40. Tetsuya, K.; Ohsawa, M. Patterns of species diversity in rural herbaceous communities under different management regimes, Chiba, central Japan. Biol. Conserv. 2002, 104, 239-249.

41. Tian, Z.H.; Song, K.; Da, L. Distribution patterns and traits of weed communities along an urban-rural gradient under rapid urbanization in Shanghai, China. Weed Biol. Manag. 2015, 15, 27-41. [CrossRef]

42. Ohtsuka, T. Early stages of secondary succession on abandoned cropland in north-east Borneo Island. Ecol. Res. 1999, 14, 281-290. [CrossRef]

43. Zhang, J.T. Quantitative Ecology; Science Press: Beijing, China, 2004. (In Chinese)

44. Chen, X.S. Distribution Pattern of Ruderal Community and Its Responses to Habitat Heterogeneity in Urban Area of Harbin. Ph.D. Thesis, East China Normal University, Shanghai, China, 2014. (In Chinese).

45. Magurran, A.E. Ecological Diversity and Its Measurement; Princeton University Press: Princeton, NJ, USA, 1988.

46. Wang, X.P.; Fang, J.Y.; Zhu, B. Forest biomass and root-shoot allocation in northeast China. For. Ecol. Manag. 2008, 255, 4007-4020. [CrossRef]

47. Zhang, K.X.; Wang, R.; Shen, C.C.; Da, L. Temporal and spatial characteristics of the urban heat island during rapid urbanization in Shanghai, China. Environ. Monit. Assess. 2010, 169, 101-112. [CrossRef] [PubMed]

48. McKinney, M.L. Urbanization as a major cause of biotic homogenization. Biol. Conserv. 2006, 127, $247-260$. [CrossRef]

49. He, R.X.; Yang, F.; Yan, P.B.; Wei, J.Y. Comparison in plant diversity in Haikou, Sanya and Wenchang cities of Hainan Province, southern China. J. Beijing For. Univ. 2019, 41, 107-115. (In Chinese)

50. Kang, M.Y. Urban Ecology and Urban Environment; China Metrology Publishing House: Beijing, China, 1997. (In Chinese)

51. Yang, S.H. Urban Ecology and Environment; Science Press: Beijing, China, 2003. (In Chinese)

52. Qiu, G.Y.; Zhang, X.N. China's urbanization and its ecological environment challenges in the 21st century. Adv. Earth Sci. 2019, 34, 640-649. (In Chinese) 
53. Da, L.J.; Ohsawa, M. Abandoned pine-plantation succession and the influence of pine mass-dieback in the urban landscape of Chiba, central Japan. Jpn. J. Ecol. 1992, 42, 81-93.

54. Zdeňka, L.; Ingolfkýü, M.C. Patterns of plant traits in annual vegetation of man-made habitats in central Europe. Perspect. Plant Ecol. Evol. Syst. 2006, 8, 69-81.

55. Peng, Y.; Liu, X.H. Research progress in effects of urbanization on plant biodiversity. Biodivers. Sci. 2007, 15, 558-562. (In Chinese)

56. Zhang, N.; Dong, L.; Wang, D.; Wang, K. Survey and analysis of the composition and distribution pattern of herbaceous plants in Beijing urban ecological corridors. Chin. Landsc. Archit. 2018, 34, 94-99. (In Chinese)

57. Jiang, Y.; Liu, S. Flora features under urban land use. J. Nat. Resour. 1999, 14, 359-362. (In Chinese)

58. Prach, K. Spontaneous succession in Central-European man-made habitats: What information can be used in restoration practice? Appl. Veg. Sci. 2003, 6, 125-129. [CrossRef]

59. Meng, X.S.; Ouyang, Z.Y.; Cui, G.F.; Li, W.F.; Zheng, H. Composition of plant species and their distribution patterns in Beijing urban ecosystem. Acta Ecol. Sin. 2004, 24, 2200-2206. (In Chinese)

60. Li, J.Y.; Wang, H.Y.; Chen, H.X. On species composition and distribution of wild herbs in central districts of Chongqing. J. Southwest China Norm. Univ. (Nat. Sci. Ed.) 2018, 43, 103-109. (In Chinese)

61. Wang, X.Y. The Study on Plant Diversity and Distribution Pattern in Sheshan District. Master's Thesis, East China Normal University, Shanghai, China, 2006. (In Chinese).

62. Song, Y.C.; You, W.H.; Wang, X.R. Urban Ecology; East China Normal University Press: Shanghai, China, 2000. (In Chinese)

63. Li, J.S.; Gao, J.X.; Zhang, X.L.; Zheng, X.M. Effects of urbanization on biodiversity. Chin. Ecol. 2005, 24, 953-957. (In Chinese)

64. Wu, C.P.; Vellend, M.; Yuan, W.G.; Jiang, B.; Yu, M. Patterns and determinants of plant biodiversity in non-commercial forests of eastern china. PLoS ONE. 2017, 12, e0188409. [CrossRef]

65. Kowarik, I. Kritische Anmerkungen zum theoretischen Konzept der potentiellen natürlichen vegetation mit anregungen zu einer zeitgemäßen modifikation. Tuexenia 1987, 7, 53-67.

66. Mckinney, M.L. Urbanization, biodiversity, and conservation. Bioscience 2002, 52, 883-890. [CrossRef]

67. Grimm, N.B.; Pickett, S.T.A.; Hale, R.L.; Cadenasso, M.L. Does the ecological concept of disturbance have utility in urban Social-Ecological-Technological systems? Ecosyst. Health Sustain. 2017, 3, e01255. [CrossRef]

68. Liu, Z.M.; Zhao, X.Y.; Liu, X.M. Relationship between disturbance and vegetation. Acta Prataculturae Sin. 2002, 11, 1-9. (In Chinese)

69. Štefanić, E.; Kovačević, V.; Antunović, S.; Japundžić-Palenkić, B.; Zima, D.; Turalija, A.; Nestorović, N. Floristic biodiversity of weed communities in arable lands of Istria Peninsula (From 2005 to 2017). Ekológia (Bratislava) 2019, 38, 166-177. [CrossRef]

70. Da, L.J.; Tian, Z.H.; Wang, C.X.; Wang, J. Biological invasion from the perspective of ecology. Chin. J. Nat. 2007, 29, 152-158. (In Chinese)

(C) 2020 by the authors. Licensee MDPI, Basel, Switzerland. This article is an open access article distributed under the terms and conditions of the Creative Commons Attribution (CC BY) license (http://creativecommons.org/licenses/by/4.0/). 